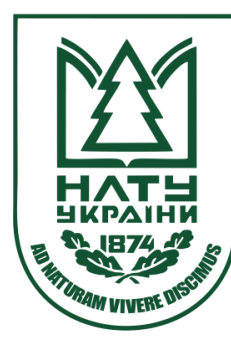

Науковий вісник НлтУ України Scientific Bulletin of UNFU

ISSN 1994-7836 (print)

https://nv.nltu.edu.ua

https://doi.org/10.15421/40280922

T. V. Shevchuk

Article received 02.07.2018 p.

Article accepted 25.10.2018 p.

shev_tana@ukr.net

удк 336.77:332.2

Т. В. Шевчук, Г. Т. Кравчук

Львівський навчально-науковий інститут ДВНЗ "Університету банківської справи", м. Львів, Украӥна

\title{
СТАН І ПЕРСПЕКТИВИ РОЗВИТКУ ІНФОРМАЦІЙНИХ ТЕХНОЛОГІЙ В УКРАЇНІ
}

Розглянуто актуальність інформаційних технологій, як одного з найважливіших чинників стимулювання економічного зростання та розвитку громадянського суспільства, зайнятості населення, соціального та політичного розвитку нашої країни. Встановлено, що на сучасному етапі переходу світового співтовариства до інформаційного суспільства ступінь розвитку інформаційних технологій стає безпосереднім чинником становлення активного та свідомого громадянина, національної конкурентоспроможності. Проаналізовано динаміку внутрішнього ринку інформаційних технологій та розглянуто вплив ITсектору на економіку України в питаннях зростання валютних надходжень, експорту IT-послуг, збільшення відрахувань у бюджет. З'ясовано, що саме рівень технологічного розвитку визначає не лише економічний потенціал країни та якість життя iї громадян, а також роль і місце цієї країни в глобальному суспільстві, масштаби та перспективи ії економічної та політичної інтеграції з усім світом. За результатами дослідження оцінено внутрішні перешкоди, з якими стикається український сектор інформаційних технологій, виявлено проблеми щодо попиту на IT серед населення України. Запропоновано напрями подолання цифрової нерівності способом впровадження міжнародних стандартів і кращих практик, зокрема 3 питань розроблення, впровадження та використання інформаційних технологій, продуктів і послуг, за умови належного наукового, технічного і правового забезпечення реформування галузі інформаційних технологій.

Ключові слова: інформаційні технології; IT-сектор; Internet-сервіси; хмарні технології; цифрова економіка.

Вступ. Рівень технологічного розвитку країни визначає ії економічний потенціал та якість життя громадян, а також роль і місце в глобальному суспільстві, масштаби та перспективи економічної й політичної інтеграції з усім світом. Одним із найбільш важливих чинників стимулювання економічного зростання та розвитку громадянського суспільства, зайнятості населення, розширення конкуренції є інформаційні технології (IT). Вітчизняний ринок інформаційних технологій перебуває на стадії активного становлення, зокрема: підвищується рівень комп'ютеризації підприємств, розширюється мережа доступу до Інтернету, зафіксовано відчутне збільшення експорту української програмної продукції. Тому сьогодні актуальними залишаються питання, які досліджують вплив IT на економічний, соціальний та політичний розвиток нашої країни.

Перспективи розвитку та роль IT у розбудові сучасної, конкурентоспроможної економіки країни неодноразово розглядали в працях вітчизняні та зарубіжні науковці: В. Геєць, А. Мазаракі, А. Маслов, В. Міщенко, В. Плескач, Т. Тадаскіна, О. Чубукова, С. Андрєєв, Д. Белл, П. Друкер, Я. Жаліло, М. Кастельс, Е. Тоффлер. Проте питання впровадження, використання, ефективного управління, фінансування та державної підтримки української IT-індустрії є актуальними та потребують дослідження.
Метою роботи є аналіз стану інформаційних технологій у світі та в Україні, їх впливу на економічний розвиток держав.

Викладення основного матеріалу. На сучасному етапі переходу світового співтовариства до інформаційного суспільства ступінь розвитку інформаційного простору та інформаційних технологій стає безпосереднім чинником становлення активного та свідомого громадянина, національної конкурентоспроможності. Інформатизація суспільства - це глобальний соціальний процес, особливість якого полягає в тому, що домінуючим видом діяльності у сфері суспільного виробництва $є$ збір, нагромадження, продукування, оброблення, зберігання, передача та використання інформації, здійснювані на основі сучасних засобів мікропроцесорної та обчислювальної техніки, а також на базі різноманітних засобів інформаційного обміну, що забезпечує: активне використання інтелектуального потенціалу суспільства, зосередженого в друкованому фонді, в науковій, виробничій та інших видах діяльності його членів; інтеграцію інформаційних технологій в наукових та виробничих видах діяльності, ініціюючий розвиток усіх сфер суспільного виробництва, інтелектуалізацію трудової діяльності; високий рівень інформаційного обслуговування, доступність будь-якого члена суспільства до джерел достовірної інформації, візуалізацію представ-

Інформація про авторів:

Шевчук Тетяна Віталіївна, канд. екон. наук, доцент, кафедра інформаційних технологій та вищої математики.

Email: shev_tana@ukr.net

Кравчук Галина Теодорівна, канд. пед. наук, доцент, кафедра інформаційних технологій та вищої математики.

Email: halyna.kravch@gmail.com

Цитування за ДстУ: Шевчук Т. В., Кравчук Г. Т. Стан і перспективи розвитку інформаційних технологій в Україні. Науковий вісник НлтУ України. Серія Економічна. 2018, т. 28, № 9. С. 114-118

Citation APA: Shevchuk, T. V., \& Kravchuk, H. T. (2018). Current state and development prospects of information technologies in Ukraine. Scientific Bulletin of UNFU, 28(9), 114-118. https://doi.org/10.15421/40280922 
леної інформації, істотність використовуваних даних (Technology, 2018).

На інтелектуальних ресурсах, наукомістких та інформаційних технологіях базується сучасна глобальна економіка, сутність якої полягає в якісно новому інноваційно-технологічному рівні всіх їі секторів, включаючи діючі продуктивні сили суспільства. Розвинуті IT відкривають шлях національній економіці до вищого рівня розвитку, оскільки цей ринок $є$ ефективним інструментом інтеграції до світового економічного простору внаслідок його особливостей, таких як: інтернаціональність (завдяки інформаційно-комунікаційній природі); привабливість для інвесторів (завдяки швидкій окупності інвестицій і високій прибутковості); наукомісткість (завдяки розвитку і реалізації наукового потенціалу підвищується рівень інформаційної й економічної безпеки країни).

Сучасний розвиток IT здатний принципово змінити життя людей - їх працю, дозвілля, способи об'єднання у співтовариства і навіть ставлення до самих себе. Фундаментальні зміни в розвитку IT впливають на наше розуміння часу, простору, відстані та знання, на відміну від попередніх кардинальних технологічних змін, заснованих на матерії та енергії. В сучасному світі знання й інформація породжують нові знання. Їхні обсяги та вплив на продуктивний розвиток суспільства зростають у часі надзвичайно високими темпами, що зумовлює необхідність розробки людством нових способів і засобів поширення та використання глобальних знань для подальшого прогресу, що і є головною властивістю суспільства знань та інформації (Torkatiuk et al., 2013).

Найбільш вагомим є вплив Інтернету. Глобальна мережа надала можливості для створення абсолютно нового сегменту онлайн-стартапів, які вийшли на глобальний ринок із майже трьома мільярдами користувачів Iнтернету завдяки низьким витратам на реалізацію. Найбільші з цих стартапів, Google i Facebook, на сьогодні є лідерами IT-компаній у світі (Global, 2015).

Сучасні розвинені держави приділяють величезну увагу розвитку інформаційно-комунікаційних технологій. Такі країни, як Індія, Ірландія, Південна Корея, Малайзія, Тайвань, Китай, Сінгапур, Фінляндія, Ізраїль, подолали межу "цифрового розриву" завдяки добре розробленим та реалістичним стратегіям розвитку інформаційного суспільства. Їхній досвід є особливо цікавим для нас, оскільки частка України на світовому ринку IT $є$ надзвичайно малою, а рівень розвитку інфраструктури цієї галузі є низьким (Torkatiuk et al., 2013).

Особливо активно розвиваються хмарні технології, витрати на які сягають третини світових IT-витрат. Про це свідчать дані аналітиків IDC (англ. International Data Corporation) (World, 2018). У третьому кварталі 2015 р. продаж серверів, систем зберігання даних і Ethernet-комутаторів, що використовували для розгортання хмарних сервісів, досяг 7,57 млрд дол., що на $23 \%$ більше, ніж роком раніше. Реалізацію обладнання для приватних і публічних хмар розподілили у співвідношенні 2,9 до 4,6 млрд дол., що відповідно на 18,8 і 25,9 \% більше від показників річної давності.

Найбільш швидкозростаючим ринком хмарних інфраструктур аналітики назвали Японію, де у третій чверті 2015 р. стався підйом на 47,1 \%. В Азійсько-Тихоокеанському регіоні (без урахування Японіі), Західній Європі і США продаж підвищився на 35,3, 22,1 i
20,1 \% відповідно. Водночас у Центральній і Східній Свропі зафіксовано спад на 10,2 \% через політичні та економічні проблеми, що впливають на IT-витрати (World, 2018).

Варто зазначити, що сьогодні IT-сектор є одним 3 найбільш динамічних сегментів економіки України, який активно розвивається. Незважаючи на тривалу стагнацію української економіки, експорт IT-послуг 3 України в 2017 р. зріс на $20 \%$ і становив 3,6 млрд дол. За прогнозами експертів, якщо галузі не заважати розвиватися, то до 2020 р. вона може зрости в 1,7 раза. Податкові надходження від IT-сектору в державний бюджет у 2017 р. збільшилися на 38 \% на відміно від показника попереднього року і становили 7,8 млрд грн. Інформаційні технології впевнено займають третю позицію за рівнем експортних надходжень, поступаючись тільки агробізнесу та металургії. Внесок ринку IT в економіку в 2017 р. становив близько 4 \% ВВП країни, і в наступні роки продовжуватиме збільшуватися (Disturbed, 2018).

Аналізуючи міжнародні рейтинги України за провідними індексами, можна констатувати, що ситуація не найкраща, а саме: мережева готовність у 2015 р. 71 місце зі 143 країн світу, розвиток електронного уряду ООН у 2014 р. - 87 місце у світі серед 193 країн-членів ООН, розвиток Інтернету в 2014 р. - 46 місце 3 86 країн світу, проникнення Інтернету за 2014 р. 95 місце зі 191 країни, розвиток IКТ - 79 місце зі 167 країн; електронна торгівля у 2014 р. - 58 місце зі 130 країн світу, глобальний індекс кібербезпеки - у 17 групі країн (з 29 груп країн) (Reforms, 2018).

Однак, за даними публікації (Market, 2018), у самій державі спостерігаємо позитивні тенденції: внутрішній ринок IT у 2016 р. зріс набагато сильніше, ніж у інших країн. Загальне зростання IT-ринку - $22 \%$. Водночас як розвинені світові ринки зростають не більше ніж на $5 \%$ у рік (Hrytsiuk \& Andrushchakevych, 2018).

Як відомо, ринок IT складається 3 трьох сегментів: hardware, packaged software i services. У 2016 р. всі ці сегменти показали зростання і тенденцію до росту надалі. Так, український ринок hardware зріс від 1,2 до 1,5 млрд дол.; ринок packaged software зріс від 0,11 до 0,12 млрд дол.; ринок послуг зріс від 0,18 до 0,19 млрд дол. У 2018 р. очікують, що темпи зростання ринку IT збільшаться до $30 \%$, кількість фахівців, зайнятих у галузі, зросте від 116 до 145 тис. осіб. Після збереження існуючих темпів зростання через 5 років інформаційні технології мають всі шанси вийти на друге місце в структурі українського експорту (табл. 1).

Табл. 1. Експорт ІT-індустрії в 2015-2025 рр.

\begin{tabular}{|c|c|}
\hline Рік & Експорт ІТ-індустрії, млрд дол. \\
\hline 2015 & 3,9 \\
\hline 2016 & 3,2 \\
\hline 2017 & 3,6 \\
\hline 2018 (прогно3) & 4,5 \\
\hline 2020 (прогно3) & 6,0 \\
\hline 2025 (прогно3) & 6,4 \\
\hline
\end{tabular}

За оцінками компанії GlobalLogic Україна, за сприятливих умов до 2025 р. сектор інформаційних технологій може зрости до 8,4 млрд дол., або у 2,3 раза, а кількість робочих місць збільшиться до понад 240 тис. осіб (Disturbed, 2018).

Варто зазначити, що IT-сектор щоразу частіше впливає і на внутрішню економіку України. Очікують такі результати зростання IT-сектору до 2020 р. (Distur- 
bed, 2018): зростання кількості фахівців галузі до 200 тис.; збільшення експорту IT-послуг до 6 млрд дол.; ринок IT становитиме близько 5 \% ВВП країни; вихід галузі на друге місце за рівнем експорту; збільшення ніші на світовому ринку; збільшення відрахувань у бюджет до 27 млрд грн.

Однак, незважаючи на значне зростання, український IT-ринок за світовими масштабами продовжує залишатися невеликим і становить близько $1 \%$ від загальносвітового показника. Обсяг світового ринку ITпослуг у 2017 р. перевищив 3,5 трлн дол., 3 яких більш ніж 40 \% припадають на США. Для прикладу, IT-ринок Індії оцінюють у 145 млрд дол., це в 40 разів більше, ніж в Україні. При цьому індійський ринок інформаційних технологій активно підтримується на рівні держави, чого немає в Україні. Зараз кількість ІТ-фахівців в Індії перевищує 4 млн, що в 40 разів більше, ніж в Україні. Від експорту IT-послуг на кожного українця припадає по 80 дол. Для порівняння, цей показник в Ізраїлі становить 1650 дол.

Сьогодні IT-сектор в Україні розширюється не за рахунок збільшення частки на світовому ринку, а завдяки зростанню надаваних послуг у світі. Для збільшення частки нашої країни на світовому ринку щорічні темпи зростання IT-послуг повинні перевищувати середньосвітовий рівень, забезпечуючи приріст не менше ніж 30 40 \% на рік. Досвід багатьох країн свідчить, що в процесі формування національної інформатизації проблему забезпечення широкого використання IT у всіх сферах життя суспільства необхідно поставити поруч із іншими найважливішими проблемами - подолання бідності, підвищення якості медичного обслуговування тощо.

Табл. 2. Індекс мережевої готовності (NRI) станом на 2016 p. (Report, 2016)

\begin{tabular}{|c|l|c|c|c|c|}
\hline $\begin{array}{c}\text { № } \\
\text { рейт }\end{array}$ & Країна & $\begin{array}{c}\text { Значення } \\
\text { IMГ (NRI) }\end{array}$ & $\begin{array}{c}\text { Значення } \\
\text { IMГ } \\
2015\end{array}$ & $\begin{array}{c}\text { Рівень } \\
\text { доходу }\end{array}$ & Група \\
\hline 1 & Сінгапур & 6,0 & 1 & HI & ADV \\
\hline 2 & Фінляндія & 6,0 & 2 & HI-OECD & ADV \\
\hline 3 & Швеція & 5,8 & 3 & HI-OECD & ADV \\
\hline 4 & Норвегія & 5,8 & 5 & HI-OECD & ADV \\
\hline 5 & США & 5,8 & 7 & HI-OECD & ADV \\
\hline 6 & Нідерланди & 5,8 & 4 & HI-OECD & ADV \\
\hline 7 & Швейцарія & 5,8 & 6 & HI-OECD & ADV \\
\hline 8 & Англія & 5,7 & 8 & HI-OECD & ADV \\
\hline 9 & Люксембург & 5,7 & 9 & HI-OECD & ADV \\
\hline 10 & Японія & 5,6 & 10 & HI-OECD & ADV \\
\hline 11 & Данія & 5,6 & 15 & HI-OECD & ADV \\
\hline 12 & Гонконг SAR & 5,6 & 14 & HI & ADV \\
\hline 13 & Корея & 5,6 & 12 & HI-OECD & ADV \\
\hline 14 & Канада & 5,6 & 11 & HI-OECD & ADV \\
\hline 42 & Польща & 4.5 & 50 & HI-OECD & EDE \\
\hline 64 & Україна & 4,2 & 71 & LM & EURAS \\
\hline
\end{tabular}

Примітка: класифікація за рівнем доходів відповідає класифікації Світового банку за рівнем доходу (станом на липень 2015 р.). Групова класифікація відповідає класифікації Міжнародного валютного фонду (станом на квітень 2016 р.). Рівень доходу: НІ - країни з високим рівнем доходу, які не є членами Організації економічного співробітництва і розвитку (ОЕСР); HI-OECD - країни 3 високим рівнем доходів, що входять до OECP; LM - країни 3 рівнем доходу, нижчим середнього. Групи: $\mathrm{ADV}$ - країни з розвиненою економікою; $\mathrm{EDA}$ - країни Азії; EDE - європейські ринки, що формується і розвиваються; EURAS - країни Євразії.

У доповіді "The Networked Readiness Index 2016" наведено оцінку чинників та інструментів, які дають змогу країні повною мірою використовувати IT для підвищення економічного та соціального розвитку. Очолю- ють рейтинг Сінгапур, Фінляндія та Швеція, які оцінюють за чотирма категоріями показників: 1) загальні умови для створення і використання технологій (політичні, нормативні, ділові та інвестиційний клімат); 2) мережева готовність у галузі IT (інфраструктура, доступність, кваліфікація працівників); 3) прийняття/застосування технологій трьома групами суспільства (уряд, приватний сектор, приватні особи); 4) вплив нових технологій на економічний та соціальний розвиток країни (Report, 2016). Індекс мережевої готовності (NRI) $\epsilon$ ключовим інструментом в оцінці готовності країн скористатися перевагами нових технологій i реалізувати можливості, представлені цифровими трансформаціями за пї межами.

Отже, країни, які змогли забезпечити добробут своїм громадянам, мають спільну рису: вони досягли успіху в розвитку технологій (табл. 2). Згідно 3 (Market, 2018), уряди цих країн створили відповідні умови, інноватори за рахунок вкладених коштів бізнесу отримали можливість для застосування своїх розробок, які бізнес використовував для того, щоб стати ефективнішим.

В Україні ж IT-сектор стикається із внутрішніми перешкодами, без яких розвиток ринку IT відбувався б значно швидше. За останні кілька років з країни виїхали працювати за кордон більше 10 тис. IT-фахівців, або десята частина від загальної їх кількості. Це зумовлено низьким рівнем життя в країні, політичною нестабільністю та правовою незахищеністю бізнесу від тиску 3 боку державних органів і силових структур. Така ситуація сприяла активному переїзду в інші країни окремих фахівців і цілих компаній, що призвело до втрати десятої частини доходів від IT-індустрії і відчутних репутаційних втрат для нашої країни. Ще одна 3 важливих проблем ринку - відсутність стратегії розвитку галузі та програми освіти майбутніх фахівців.

Отже, для забезпечення сталого розвитку українського IT-ринку потрібно знизити рівень державного втручання і сприяти поліпшенню бізнес-клімату в країні. Поки діловий клімат в Україні буде гіршим, ніж у сусідніх країнах, доти українські інноватори будуть реалізовувати свої стартапи на території інших держав, де для їх розвитку створено сприятливіші умови.

Окрім цього, з аналізу даних Всесвітнього економічного форуму (Readiness, 2015) видно, що за досить великого потенціалу розвитку IT в Україні практично відсутній попит як з боку населення загалом, так і з боку влади та бізнесу зокрема, на ці технології. Так, наша держава зараз знаходиться на першому місці за кількістю IT-розробників у Свропі, а ціни на інформаційно-комунікаційні послуги в нас одні 3 найнижчих у світі. Велика частина населення нашої країни, представники влади та бізнесу досі користуються можливостями IT лише на найнижчому, тривіальному рівні.

Таку ситуацію пояснюють корупційними інтересами державних чиновників, які незацікавлені в прозорості своєї діяльності, а тому всіляко пручаються впровадженню IT у приховану від громадськості державну систему перерозподілу коштів. Зокрема саме це стало першопричиною тієї очевидної недоладності, коли "Кремнієва долина" колишнього СРСР, країни з найпотужнішим науковим потенціалом і високим рівнем грамотності дорослого населення, опинилася на узбіччі експоненціального розвитку IT. Якщо в розвинених країнах держава була основним акселератором розвитку 
IT, то в Україні, навпаки, влада всіляко гальмувала розширення сфери застосування IT і штучно занижувала на них попит. Внаслідок вкорінення корупції, як невід'ємної складової державного механізму, бізнес також почав гальмувати розвиток IT у нашій країні. Підприємці в цій ситуації просто боялися виходити 3 тіні, а отже, не хотіли "світитися" з сучасними інформаційними сервісами у відкритій мережі Internet. Bсе це призвело до того, що й у населення не сформувався адекватний попит на сучасні інформаційні технології (Development, 2018; Hrytsiuk \& Nemova, 2018).

Ми погоджуємося 3 думкою про те, що одним із основних шляхів виходу з описаної ситуації $є$ прийняття комплексних регіональних програм щодо розвитку інформаційних технологій, які передбачали б активізацію діяльності всіх секторів громадянського суспільства за такими напрямами:

1. Поширення та популяризація IT у сфері адміністративного, фінансового, роздрібного та соціально-побутового обслуговування малозабезпечених та соціально незахищених громадян.

2. Впровадження та поширення IT-розробок серед громадських організацій, що сприятиме викоріненню соціальної несправедливості, забезпеченню прозорості діяльності влади та розвитку громадянського суспільства загалом.

3. Максимальне використання механізмів для стимулювання виходу бізнесу з тіні, коли для того, щоб бути конкурентоспроможним на легальному ринку, йому необхідно буде відкривати все нові й нові Web-pecyрси на основі електронної комерції та сучасних IT.

4. Удосконалення системи початкової, середньої та вищої освіти 3 тим, щоб вона максимально стимулювала активність молоді не тільки у сфері IT-розробок, але й у напрямі застосування найновіших інформаційних технологій та розробок у всіх сферах життєдіяльності: навчанні, науці, техніці, мистецтві, дизайні тощо.

У рамках поширення та популяризації IT серед малозабезпечених і соціально незахищених громадян зараз інтенсивно впроваджуються нові інформаційні Internet-сервіси, до яких зокрема належать: національний портал відкритих даних (http://data.gov.ua/); онлайнкалькулятор для розрахунку субсидій (http://bit.ly/1zTO8zf); відстеження транспорту онлайн (http://bit.ly/1OsdxZL); електронний кабінет платника податків (http://bit.ly/1HnrTLy) тощо.

Однак ці Internet-сервіси наразі маловідомі багатьом громадянам або ж вони просто не знають про них, чи бояться ними користуватися. Тому необхідно масово прививати незаможному населенню навички застосування в повсякденному житті сучасних Internet-сервісів і доводити громадянам безперечність переваг користування IT. Для цього можна було б створювати при школах, ВН3 і громадських організаціях безкоштовне навчання, де волонтери, студенти навчали б незаможних громадян навичкам роботи на комп'ютері, здійсненню безготівкових платежів тощо (Development, 2018).

Висновки. Сьогодні світове співтовариство стоїть на порозі четвертої промислової революції, яка передбачає перехід до нового набору систем, що об'єднують цифрові, біологічні та фізичні технології в нову потужну комбінацію; забезпечує доступність глобальних цифрових комунікацій; низьку вартість оброблення та високу щільність зберігання даних, а також ще тісніші взаємозв'язки населення 3 цифровими технологіями
(Report, 2016). Четверта промислова революція - це "технології цифрової трансформації": інтернет речей, роботизація та кіберсистеми, штучний інтелект, великі дані, безпаперові технології, хмарні та туманні обчислення, безпілотні та мобільні технології, біометричні технології, квантові технології, технології ідентифікації, блокчейн та ін. Цифрові технології відкривають унікальні можливості й для розвитку нашої економіки та підвищення рівня життя громадян. Застосування відкритих інформаційних систем, розрахованих на використання всього масиву інформації, доступної сьогодні суспільству в певній галузі, дає змогу вдосконалити механізми управління суспільним устроєм, сприяє гуманізації і демократизації суспільства, підвищує рівень добробуту його членів. Процеси, що відбуваються з огляду на інформатизацію суспільства, сприяють не тільки прискоренню науково-технічного прогресу, інтелектуалізації всіх видів людської діяльності, а й створенню якісно нового інформаційного середовища соціуму, що забезпечує розвиток творчого потенціалу індивіда.

3'ясовано, що подальший розвиток "цифрових трансформацій" України відбуватиметься за одним із двох сценаріїв - базовим або форсованим. Базовий сценарій, або непріоритетний, передбачає інерційне продовження тенденцій сприйняття "цифровізації" економіки та пов'язаного з цим розвитку людського капіталу як непріоритетних, що буде надалі призводити до трудової міграції та відтоку "мізків", неефективної економіки, низької конкурентоспроможності. Цей сценарій матиме лише незначний вплив на модернізацію економіки, розвиток ринку інновацій, інноваційного підприємництва та загального стану "цифровізації" країни. Форсований, або пріоритетний, сценарій цифровізації передбачає усунення законодавчих, інституційних, фіскально-податкових, валютно-грошових бар'єрів, що перешкоджають розвитку "цифрової" економіки. Для реалізації цього сценарію розроблено документ "Цифрова адженда України-2020", в якому викладено принципи розвитку України в цифровому просторі: розвиток цифрової інфраструктури як основи цифрової економіки; цифровізація реального сектору, зокрема через сприяння розвитку інфраструктури "Індустрія 4.0", "цифрового робочого місця", "смарт-фабрики"; цифровізація базових сфер життєдіяльності, зокрема через цифрову трансформацію середньої школи та розвиток STEM-освіти, запровадження е-медицини та е-безпеки, концепції "розумні міста"; розвиток цифрової грамотності населення.

А головною мотивацією держави піти по форсованому сценарію розвитку мають стати цифрові дивіденди, а саме: загальнонаціональний економічний приріст, акселерація економіки, бізнес-діяльності, а отже, і податкові надходження, зростання ВВП, притік нових інвестицій тощо.

\section{Перелік використаних джерел}

Development. (2018). Information technologies as an incentive for the socio-economic development of Ukraine. Retrieved from: http://www.gurt.org.ua/blogs/Oleksandr\%20Luk\%27ianov/1712. [In Ukrainian]

Disturbed. (2018). IT of Ukraine. To help, not to be disturbed. Retrieved from: https://news.finance.ua/ua/news/-/419649/it-ukrayinydopomagaty-ne-mozhna-zavazhaty. [In Ukrainian].

Global. (2015). The Global Information Technology Report. Retrieved from: $\quad$ http://www3.weforum.org/docs/WEF Global IT Report 2015.pdf. 
Hrytsiuk, Yu. I., \& Andrushchakevych, O. T. (2018). Means for determining software quality by metric analysis methods. Scientific Bulletin of UNFU, 28(6), 159-171. https://doi.org/10.15421/40280631

Hrytsiuk, Yu. I., \& Nemova, E. A. (2018). Management Features Process of Developing. [In Ukrainian].

Market. (2018). Ukraine on the global IT-market. Retrieved from: https://biz.nv.ua/ukr/economics/ukrajina-na-svitovomu-rinku-it-top10-najtsikavishih-faktiv-infografika-2353974.html. [In Ukrainian].

Readiness. (2015). Networked Readiness Index. Retrieved from: http://www3.weforum.org/docs/GITR15/UKR.pdf.

Reforms. (2018). Recommendations of the parliamentary hearings on the theme: "Reforms in the field of information and communication technologies and development of the information space of Ukraine". Retrieved from: http://zakon3.rada.gov.ua/laws/show/107319. [In Ukrainian]
Report. (2016). Global Information Technology Report. Retrieved from: http://reports.weforum.org/global-information-technology-report-2016.

Technology. (2018). The role of information technology in modern li$f e$. Retrieved from: http:/wiki.kspu.kr.ua/index.php/Роль_інформаційних тенологій. [In Ukrainian].

Torkatiuk, V. I., Polchaninova, I. L., Dmytruk, I. A., \& Nikbin, F. (2013). The role of information technologies in the socio-economic development of Ukraine. Formuvannia ekonomichnykh struktur zemleustroiu, budivnytstva ta upravlinnia nerukhomistiu: stan, problemy, rishennia: materialy Mizhnar. nauk.-prakt. Internetconf., (pp. 45-46). Retrieved from: http://eprints.kname.edu.ua/37947/1/45-46.pdf. [In Ukrainian].

World. (2018). One-third of IT-equipment in the world is used for cloud services. Retrieved from: http://news.finance.ua/ua/news//367493/tretyna-it-obladnannya-v-sviti-vykorystovuyetsya-dlyahmarnyh-servisiv. [In Ukrainian].

T. В. Шевчук, Г. Т. Кравчук

Львовский учебно-научный институт ГВУЗ "Университета банковского дела", г. Львов, Украина

\section{СОСТОЯНИЕ И ПЕРСПЕКТИВЫ РАЗВИТИЯ ИНФОРМАЦИОННЫХ ТЕХНОЛОГИЙ В УКРАИНЕ}

Рассмотрена актуальность информационных технологий, как один из важнейших факторов стимулирования экономического роста и развития гражданского общества, занятости населения, социального и политического развития нашей страны. Установлено, что на современном этапе перехода мирового сообщества к информационному обществу степень развития информационных технологий становится непосредственным фактором становления активного и сознательного гражданина, национальной конкурентоспособности. Проанализирована динамика внутреннего рынка информационных технологий и рассмотрено влияние IT-сектора на экономику Украины в вопросах увеличения валютных поступлений, экспорта IT-услуг, увеличение отчислений в бюджет. Выяснено, что именно уровень технологического развития определяет не только экономический потенциал страны и качество жизни ее граждан, а также роль и место этой страны в глобальном обществе, масштабы и перспективы ее экономической и политической интеграции со всем миром. По результатам исследования оценены внутренние препятствия, с которыми сталкивается украинский сектор информационных технологий, выявлены проблемы по спросу на IT среди населения Украины. Предложены направления преодоления цифрового неравенства путем внедрения международных стандартов и лучших практик, в том числе по вопросам разработки, внедрения и использования информационных технологий, продуктов и услуг, при условии надлежащего научного, технического и правового обеспечения реформирования отрасли информационных технологий.

Ключевые слова: информационные технологии; IT-сектор; Internet-сервисы; облачные технологии; цифровая экономика.

T. V. Shevchuk, H. T. Kravchuk Lviv Educational and Research Institute of Banking University, Lviv, Ukraine

\section{CURRENT STATE AND DEVELOPMENT PROSPECTS OF INFORMATION TECHNOLOGIES IN UKRAINE}

The impact of information technologies on the economic, social, and political development of our country was researched by the method of analysis. The implementation, usage, as well as effective management, financing, and government support of the Ukrainian IT industry was investigated. IT sector is currently one of the most dynamic and actively growing segments of Ukraine's economy. If the current speed of growth persists, in five years, information technologies might become the second one within Ukrainian export structure. Despite such active development, by global standards, Ukrainian IT market is rather small and constitutes approximately one per cent of the global factor. This is caused by internal obstacles such as poverty rate, political uncertainty, and legal vulnerability of business under the pressure from government and law enforcement agencies. Another important market challenge is the absence of strategy for industry development and educational program for future specialists. To ensure steady development of Ukrainian IT market, state intervention should decrease, and business climate in the country should be stabilized, spread and popularize information technologies among the poor and socio vulnerable citizens due to intensive introduction of new information Internet services. For this, it is suggested to use several ways of reducing the digital gap among the people by implementing comprehensive regional programs for information technology development. These programs include activating all sectors of civil society, as well as using global standards and best practices for development, implementation, and usage of information technologies, products, and services in the conditions of proper scientific, technical, and legal support for information technology reorganization. Country should be highly motivated to support economy digitalization by digital dividends, including national economic growth, economy and business acceleration, as well as subsequent tax revenues, GDP growth, increase in the number of industry professionals, increased IT services export, new investments, etc.

Keywords: information technologies; IT sector; Internet-based services; cloud technologies; digital economics. 